\title{
Pertumbuhan dan Produksi Galur-Galur Padi Toleran Fe Generasi F8 Hasil Persilangan IR64 x Hawara Bunar di Lahan Pasang Surut, Banyuasin, Sumatera Selatan
}

\author{
Growth and Production of Fe Tolerant Rice Lines F8 \\ Generation Derived from a Cross between IR64 x Hawara \\ Bunar in Tidal Soil, Banyuasin, South Sumatera
}

\author{
LA KOLAKA ${ }^{1}$, MUNIF GHULAMAHDI ${ }^{2}$, MIFTAHUDIN ${ }^{3 *}$

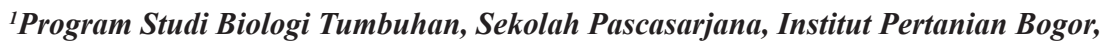 \\ Kampus Darmaga, Bogor 16680, Indonesia \\ ${ }^{2}$ Departemen Agronomi dan Hortikultura Fakultas Pertanian, Institut Pertanian Bogor, \\ Kampus Darmaga, Bogor 16680, Indonesia \\ ${ }^{3}$ Departemen Biologi, Fakultas Matematika dan Ilmu Pengetahuan Alam, \\ Institut Pertanian Bogor, Kampus Darmaga, Bogor 16680, Indonesia
}

Diterima 16 Maret 2015/Disetujui 30 April 2015

\begin{abstract}
Utilization of marginal lands such as tidal land should be done to increase rice production as a solution of the decreasing productive land. However, rice cultivation in such land will be affected by low soil fertility, soil acidity and Fe toxicity. Fe-tolerant varieties are needed to overcome those problems. The objective of the research was to analyze the growth and production of Fe tolerant rice lines in tidal soil type C, Banyuasin, South Sumatera. Screening for Fe-tolerant character of 54 rice lines from the F8 RIL population derived from a cross between rice var. IR64 and var. Hawara Bunar using hydroponic technique under $1000 \mathrm{ppm}$ Fe resulted $25 \mathrm{Fe}$-tolerant lines. The field test of 25 putative tolerant rice lines, at the tidal land in Banyuurip, Banyuasin, showed that the most lines grew better than that of var. Hawara Bunar parent. Several lines produced yield higher than that of var. Hawara Bunar parent. The field experiment resulted two rice lines, which were IRH108 and IRH195 that potential for further studies.
\end{abstract}

Key words: bronzing, iron toxicity, rice, tidal land

\section{PENDAHULUAN}

Usaha meningkatkan produksi padi melalui peningkatan produktivitas padi dan luas lahan produksi harus terus dilakukan untuk mengimbangi peningkatan konsumsi beras. Perluasan lahan terkendala oleh ketersediaan lahan yang cocok untuk pertanian, sementara lahan marginal produktivitasnya rendah. Salah satu upaya yang dapat dilakukan untuk meningkatkan produksi padi adalah dengan melakukan seleksi galur-galur adaptif lahan marginal seperti lahan pasang surut.

Lahan pasang surut berdasarkan pola genangan pasang terbagi ke dalam 4 tipe, yaitu tipe A (tergenang saat pasang besar dan kecil), tipe $\mathrm{B}$ (tergenang saat pasang besar), tipe $\mathrm{C}$ (tidak tergenang kedalaman air tanah $<50 \mathrm{~cm}$ ), dan tipe D (tidak tergenang

*Penulis korespondensi. Phone/Fax: +62-251-8622833, E-mail: miftahudin@ipb.ac.id kedalaman air tanah $>50 \mathrm{~cm}$ ) (Widjaja-Adhi et al. 1997). Lahan tipe C dan D inilah yang berpotensi digunakan untuk pengembangan lahan pertanian baru.

Karakteristik tanah pasang surut memiliki karakteristik umumnya memiliki lapisan tanah aluvial (endapan) atau gambut, lapisan pirit $\left(\mathrm{Fe}_{2} \mathrm{~S}\right)$ yang tinggi, dan kadar garam lebih tinggi. Pirit dalam keadaan kering teroksidasi menjadi asam sulfat dan menimbulkan tanah menjadi asam, sehingga disebut tanah sulfat masam, yang menghambat pertumbuhan tanaman (Widjaja-Adhi et al. 1997).

Usaha peningkatan produksi padi di lahan pasang surut banyak diarahkan pada perbaikan varietas padi yang tahan terhadap lahan pasang surut. Pada umumnya padi hibrida yang dilepas pemerintah maupun swasta masih mempunyai kelemahan, seperti kerentanan penyakit, dan bersifat spesifik lokasi, sehingga perlu terus dilakukan pengujian secara 
terus-menerus (Satoto dan Suprihatno 2008). Pada tahun 1986 dilepas varietas IR64 dengan karakter penampilan baik, potensi hasil tinggi, umur genjah (115 hari), mutu beras baik dan rasa nasi enak, tapi peka terhadap penyakit hawar daun bakteri strain IV dan hawar daun jingga (Silitonga 2004). Padi lokal var. Hawara Bunar (BB Biogen 2010) memiliki karakter tahan pada tanah masam PMK Tamanbogo, toleran terhadap Al, toleran kekeringan dan tahan penyakit blas (Daradjat et al. 2009). Karena tahan tanah masam, padi varietas Hawara Bunar kemungkinan tahan juga pada kondisi yang berasosiasi dengan tanah masam seperti cekaman Fe. Studi awal pada skala laboratorium yang dilakukan oleh Amnal (2009) dan Suryadi (2012) menunjukkan bahwa varietas Hawara Bunar memiliki potensi sebagai tetua untuk menghasilkan galur-galur adaptif lahan pasang surut.

Karakter utama yang menjadi pertimbangan dalam proses pengembangan padi lahan pasang surut adalah potensi produktivitas yang tinggi dan mampu beradaptasi pada kondisi tanah berkadar besi (Fe) tinggi (Humairil \& Khairullah 2000; Audebert et al. 2006). Pemulia tanaman biasanya menyilangkan varietas unggul dengan produktivitas tinggi dengan varietas lokal yang beradaptasi baik pada lahan marginal. Di Departemen Biologi IPB telah diperoleh galur-galur padi hasil persilangan var. IR64 dengan var. Hawara Bunar. Galur-galur tersebut perlu diseleksi untuk mendapatkan karakter vegetatif dan reproduktif yang mendukung kemampuan beradaptasi pada lingkungan marginal lahan pasang surut.

Penelitian pengujian cekaman Fe dengan menggunakan media cair (kultur hara), media tanah pada pot, dan pada percobaan lapang sudah banyak dilakukan pada berbagai kondisi lingkungan dan genotipe tanaman padi (Audebert \& Sahrawat 2000; Sutami et al. 2003; Sutami 2004; Asch et al. 2005; WARDA 2002; Kustianto et al. 2008; Cherif et al.. 2009). Hasil percobaan hidroponik dengan menggunakan larutan Yoshida half stregth $1000 \mathrm{ppm}$ $\mathrm{Fe}$ (Suryadi 2012) menunjukkan respon toleransi galur-galur padi F7 hasil silangan var. IR64 x var. Hawara Bunar yang diuji hampir setara dengan respon toleransi galur-galur hasil percobaan rumah kaca dan percobaan lapang pada sawah dengan kandungan Fe 338 ppm.

Penelitian ini dilakukan pada lahan pasang surut di Kabupaten Banyuasin, suatu wilayah yang memiliki lahan pasang surut yang luas (200.000 ha) dan merupakan sentra produksi padi di Sumatera Selatan (Agus \& Subiksa 2008). Di wilayah ini sudah biasa diusahakan budidaya padi sawah pasang surut pada musim hujan dan budidaya palawija pada musim kemarau oleh masyarakat setempat. Penelitian ini diharapkan dapat memperoleh galur-galur padi potensial untuk lahan pasang surut dengan karakter agronomi dan produksi yang lebih baik dari kedua tetuanya.

Penelitian ini bertujuan untuk (1) menapis galurgalur padi generasi F8 turunan persilangan var. IR64 x var. Hawara Bunar pada cekaman Fe 1000 ppm dalam larutan hara Yoshida half strength, dan (2) mempelajari karakteristik pertumbuhan dan kemampuan produksi dari galur-galur padi tersebut pada lahan pasang surut tipe luapan $\mathrm{C}$ pada musim penghujan.

\section{BAHAN DAN METODE}

Bahan Penelitian. Bahan tanaman padi yang digunakan adalah biji dari galur-galur keturunan var. IR64 x var. Hawara Bunar generasi F8 (54 galur), dan 3 varietas pembanding (IR64, Hawara Bunar, dan Mahsuri) untuk penapisan pada kultur hara. Percobaan uji lapang menggunakan 25 galur toleran $\mathrm{Fe}, 5$ galur rentan, dan 5 varietas pembanding (IR64, Hawara Bunar [HB], Mahsuri [MH], Indragiri [IG] dan Inpari 13 [IP13]).

Percobaan Kultur Hara. Percobaan kultur hara dilakukan di Rumah Kaca Departemen Biologi IPB. Biji padi 57 nomor sampel dikecambahkan dalam wadah plastik selama 6 hari dalam kondisi gelap. Setelah berkecambah, padi ditumbuhkan pada media penyokong styrofoam dalam potongan pipa $3 / 4$ inchi yang diapungkan dengan styrofoam dalam kultur hara larutan Yoshida half-strength $\mathrm{pH} 4.5$ pada wadah plastik yang berukuran permukaan $46 \mathrm{~cm}$ x $36 \mathrm{~cm}$ dan volume larutan hara 14 liter. Percobaan dirancang dengan Rancangan Acak Kelompok faktor genotipe padi dengan 3 ulangan. Larutan hara diganti tiap 7 hari sampai tanaman berumur 21 hari. Pada umur 21 hari, tanaman ditumbuhkan pada cekaman $\mathrm{Fe} 1000$ ppm dalam larutan Yoshida half-strength selama 7 hari. Umur 28 hari tanaman diamati persen bronzing daun berdasarkan SES IRRI yang dimodifikasi oleh Asch et al. (2005).

Percobaan Lapang. Percobaan merupakan percobaan faktor tunggal (genotipe padi) dengan menggunakan Rancangan Acak Kelompok Lengkap (RAKL) dengan 3 ulangan. Tiap ulangan digunakan 7 sampel tanaman pengamatan. Metode penananam di lapang menggunakan metode stripe check yaitu menempatkan tanaman pembanding varietas padi peka keracunan $\mathrm{Fe}$ dan toleran keracunan $\mathrm{Fe}$ memanjang sejajar dengan plot-plot galur yang diuji. Jarak tanam adalah $25 \mathrm{~cm}$ x $30 \mathrm{~cm}$ dalam petak 10 
tanaman per baris, 4 baris per petak. Panjang dan lebar petak $2.5 \mathrm{~m} \mathrm{x} 1 \mathrm{~m}$. Bibit dipindah setelah tanaman mencapai berumur 21 hari. Pemupukan dilakukan dengan $250 \mathrm{~kg}$ urea dan $100 \mathrm{~kg}$ TSP, 75 $\mathrm{kg} \mathrm{KCl}$ per hektar dan diberikan dua tahap yaitu pada umur 3 dan 7 MST.

Peubah pertumbuhan dan produksi yang diamati dan diukur yaitu:

1. Tinggi tanaman $(\mathrm{cm})$ umur $7 \mathrm{MST}$, diukur dari pangkal batang sampai ujung daun tertinggi

2. Jumlah anakan (anakan) umur 7 minggu setelah tanam

3. Tinggi tanaman $(\mathrm{cm})$ maksimum umur produktif diukur dari pangkal sampai ujung daun tertinggi.

4. Jumlah anakan produktif (anakan) dihitung setelah berbunga

5. Umur berbunga (HST) dihitung dari saat tanaman padi berbunga $50 \%$.

6. Umur panen (HST) dihitung saat tanaman padi dari tanam sampai umur panen

7. Panjang malai $(\mathrm{cm})$ dihitung dari batas buku leher sampai ujung malai

8. Jumlah biji per malai dihitung semua biji tiap malai dalam tiap rumpun sampel

9. Bobot biji per malai (g) dihitung dengan menimbang biji isi per malai tiap rumpun sampel.

10. Persen gabah isi/malai (\%) dihitung jumlah biji bernas terhadap biji hampa dalam satu malai $\mathrm{x}$ $100 \%$, pada sampel 7 rumpun/plot.

11. Bobot 1000 biji (g) dilakukan dengan menimbang 1000 biji bernas dari setiap galur per petak.

12. Produksi per hektar ( $\mathrm{t} / \mathrm{ha})$ ditimbang produksi dari 16 rumpun sampel tiap petak (g) lalu dikonversi ke produksi per hektar
13. Biomassa tajuk dan akar (g) diambil secara acak 1 rumpun per petak yang diambil pada umur 7 MST dan umur produksi.

Metode pengamatan berdasarkan Panduan Karakterisasi dan Evaluasi Tanaman Padi (Moeljopawiro et al. 2003)

Analisis Data. Data hasil pengamantan pada percobaan kulur hara dan percobaan lapang dianalisis dengan Sidik Ragam pada tingkat kepercayaan 95\%. Data yang berbeda signifikan dilanjutkan dengan uji Duncan (DMRT) pada $\alpha=0.05$.

\section{HASIL}

Bronzing Daun pada Kultur Hara. Dari 54 galur yang diuji terdapat 12 galur dengan skor bronzing 3 (kelompok toleran Fe). Duabelas galur tersebut adalah IRH1, IRH97, IRH108, IRH161, IRH437, IRH468, IRH531, IRH549, IRH629, IRH634, IRH654, IRH715. Selain itu diperoleh 13 galur dengan skor bronzing 5 (moderat toleran $\mathrm{Fe}$ ) yaitu IRH94, IRH135, IRH153, IRH195, IRH281, IRH286, IRH438, IRH452, IRH508, IRH581, IRH699, IRH786, IRH787 (Tabel 1). Akan tetapi tidak satupun diperoleh galur yang sangat toleran terhadap cekaman Fe konsentrasi1000 ppm. Varietas pembanding Hawara Bunar, IR64 dan Mahsuri masing-masing memiliki skor bronzing 7 (rentan), 5 (moderat), dan 1 (sangat toleran).

Pertumbuhan Padi pada Percobaan Lapang. Tinggi tanaman maksimum terdapat perbedaan yang nyata antar galur (Tabel 2). Terdapat 23 galur lebih pendek dan 2 galur lebih tinggi dari var. Hawara Bunar. Jika dibandingkan dengan var. Indragiri terdapat 14 galur yang lebih tinggi dan 7 galur yang lebih pendek dari tinggi var. Indragiri (Tabel 3).

Tabel 1. Persen (\%) dan skor bronzing dari 54 galur F8 turunan var. IR64 x var. Hawara Bunar

\begin{tabular}{|c|c|c|c|c|}
\hline \multirow{2}{*}{ Tingkat Toleransi } & \multicolumn{2}{|c|}{ Bronzing } & \multirow{2}{*}{$\sum$ Galur } & \multirow{2}{*}{ Nomor Galur-galur yang diuji (IRH-) } \\
\hline & $(\%)$ & (Skor) & & \\
\hline Sangat toleran & $1-9$ & 1 & 0 & \\
\hline Toleran & $10-29$ & 3 & 12 & $1,97,108,161,437,468,531,549,629,634,654,715$ \\
\hline Moderat & $30-49$ & 5 & 13 & $94,135,153,195,281,286,438,452,508,581,699,786,787$ \\
\hline Sensitif & $50-69$ & 7 & 18 & $\begin{array}{l}67,217,241,246,255,342,374,406,414,430,473,479,519,560,561, \\
574,663,786\end{array}$ \\
\hline Sangat sensitif & $70-89$ & 9 & 11 & $163,181,187,193,205,283,322,330,351,440,447$ \\
\hline
\end{tabular}

Tabel 2. Rangkuman nilai p hasil sidik ragam 8 peubah percobaan lapang

\begin{tabular}{lcccccccc}
\hline \multirow{2}{*}{ Sumber } & \multicolumn{8}{c}{ Nilai $\mathrm{p}$} \\
\cline { 2 - 9 } & 1 & 2 & 3 & 4 & 5 & 6 & 7 & 8 \\
\hline Ulangan & $0.023^{*}$ & 0.157 tn & 0.071 tn & 0.438 tn & $0.028^{*}$ & 0.140 tn & $0.020^{*}$ & $0.014^{*}$ \\
Galur & $0.000^{*}$ & $0.000^{*}$ & $0.000^{*}$ & $0.000^{*}$ & $0.000^{*}$ & $0.000^{*}$ & $0.000^{*}$ & $0.000^{*}$ \\
\hline
\end{tabular}

$*$ = beda nyata $(0.05)$, $\mathrm{tn}=$ beda tidak nyata, $1=$ tinggi tanaman produktif $(\mathrm{cm}), 2=$ jumlah anakan produktif, $3=$ panjang malai $(\mathrm{cm}), 4=$ jumlah biji per malai $(\mathrm{cm}), 5=$ bobot biji per malai $(\mathrm{g}), 6=$ persen gabah isi, 7 = produksi (ton $/ \mathrm{ha}), 8=$ bobot 1000 biji $(\mathrm{g})$. 
Jumlah anakan produktif berbeda nyata antar galur (Tabel 2). Terdapat 29 galur menghasilkan lebih banyak anakan produktif dibanding dengan var. Hawara Bunar. Jika dibandingkan dengan var. Indragiri terdapat 25 galur lebih sedikit anakan dari anakan var. Indragiri (Tabel 3).

Perkembangan dan Hasil Padi pada Percobaan Lapang. Umur panen bervariasi dari 103 sampai 132 HST. Mayoritas galur yang diuji memiliki umur panen kurang dari umur panen tetua var. Hawara Bunar, hanya galur IRH330 dan IRH438 yang relatif sama dengan tetua HB (Tabel 4). Panjang malai berbeda nyata antar galur (Tabel 2). Terdapat 24 galur yang menghasilkan malai lebih pendek dari malai var. Hawara Bunar (Tabel 3), tetapi jika dibandingkan dengan malai var. Indragiri terdapat 5 galur lebih panjang dan hanya ada satu galur lebih pendek dari malai var. Indragiri (Tabel 3). Galurgalur yang menghasilkan malai lebih panjang dari var. Indragiri antara lain berurut ke lebih panjang IRH438, IRH1, IRH283, IRH135, IRH161, IRH468, IRH437, IRH330, IRH286, IRH195, IRH786, IRH108, IRH193 dan HB.

Jumlah biji per malai berbeda antar galur yang diuji (Tabel 2). Dari galur-galur yang diuji, hanya ada 2 galur menghasilkan jumlah biji per malai lebih banyak dari var. Hawara Bunar dan 3 galur menghasilkan jumlah biji per malai lebih banyak dari jumlah biji per malai var. Indragiri (Tabel 3).

Bobot gabah isi per malai berbeda nyata antar galur (Tabel 2). Tidak ada galur yang menghasilkan bobot gabah isi per malai yang lebih tinggi dari var. Hawara Bunar, tetapi terdapat 5 galur yang menghasilkan bobot gabah isi per malai lebih besar dari var. Indragiri (Tabel 3) dan 3 galur menghasilkan persen gabah isi yang lebih tinggi dari var. Indragiri (Tabel 3). Kalau dilihat dari bobot 1000 butir, sebagian besar galur (21 galur) menghasilkan ukuran gabah yang lebih besar dari ukuran gabah var. Indragiri.

Produksi gabah kering per hektar berbeda nyata antara galur (Tabel 2). didapatkan satu galur lebih banyak (MH) dan 4 galur lebih sedikit produksinya dari produksi var. Hawara Bunar (Tabel 3). Apabila dibandingkan dengan var. Indragiri terdapat 14 galur lebih sedikit dari var. Indragiri (Tabel 3). Galur IRH108 menghasilkan gabah kering per hektar sebesar 5.05 ton yang melebihi var. Hawara Bunar. Akan tetapi, tidak ada satupun galur turunan var. IR64 $\mathrm{x}$ var. Hawara Bunar yang memiliki produksi gabah kering per hektar melebihi produksi var. Indragiri. Galur IRH108 menghasilkan gabah kering per hektar sebesar 5.05.ton, di atas produksi var. Hawara Bunar dan di bawah produksi var. Indragiri.

Galur Padi Potensial Toleran Fe. Dari 32 galur yang ditanam pada percobaan lapang, terdapat 25 galur yang bertahan sampai panen, sedangkan 7 galur sisanya terserang penyakit hawar pelepah, blast pelepah, hawar daun dan blast leher malai seperti pada Gambar 1. Untuk menentukan galurgalur yang berpotensi untuk dikembangkan sebagai galur yang beradaptasi pada lahan pasang surut,

Tabel 3. Jumlah genotipe dengan karakter agronomi yang berbeda nyata dengan karakter agronomi arietas pembanding Hawara Bunar dan Indragiri

\begin{tabular}{|c|c|c|c|c|c|c|}
\hline \multirow{2}{*}{ Peubah } & \multirow{2}{*}{ Nilai Peubah HB } & \multicolumn{2}{|c|}{ Jumlah Genotipe berbeda dengan HB } & \multirow{2}{*}{ Nilai Peubah IG } & \multicolumn{2}{|c|}{ Jumlah Genotipe berbeda dengan IG } \\
\hline & & $<\mathrm{HB}$ & $>\mathrm{HB}$ & & $<\mathrm{IG}$ & $>\mathrm{IG}$ \\
\hline TTP & 156.7 & 23 & 2 & 120.7 & 7 & 14 \\
\hline JAP & 5.2 & 0 & 29 & 16.5 & 25 & 0 \\
\hline PM & 32.3 & 24 & 0 & 23.7 & 1 & 5 \\
\hline$\Sigma \mathrm{BM}$ & 173.1 & 17 & 2 & 144.7 & 12 & 3 \\
\hline BBM & 6.2 & 24 & 0 & 2.5 & 3 & 5 \\
\hline GI & 87.6 & 14 & 0 & 72.7 & 5 & 3 \\
\hline Prod & 4.83 & 4 & 1 & 6.13 & 14 & 0 \\
\hline B1000 & 41.6 & 24 & 0 & 23.8 & 1 & 21 \\
\hline
\end{tabular}

$\mathrm{HB}=$ Hawara Bunar, IG = Indragiri, TTP = tinggi tanaman produktif $(\mathrm{cm}), \mathrm{JAP}=$ jumlah anakan produktif, $\mathrm{PM}=$ panjang malai (cm), $\Sigma \mathrm{BM}=$ jumlah biji/malai, $\mathrm{BBM}=$ bobot biji/malai $(\mathrm{g}), \mathrm{GI}=$ persen gabah isi/malai, Prod= produksi gabah kering panen/ha (ton), $\mathrm{B} 1000=$ bobot 1000 biji (g).

Tabel 4. Umur panen dan jumlah galur produktif sesuai umur panen pada percobaan lapang

\begin{tabular}{lrrrrrrrr}
\hline Parameter & \multicolumn{7}{c}{ Variasi umur dan jumlah genotipe yang dipanen } \\
\hline Umur Panen (HST) & 103 & 105 & 107 & 111 & 112 & 114 & 119 & 132 \\
Jumlah Galur & 15 & 3 & 1 & 2 & 1 & 1 & 1 & 1 \\
\hline Keterangan Galur* & & & IRH153 & HB, IRH330 & IRH438 & IP13 & IG & MH \\
\hline
\end{tabular}

* Galur pada umur panen 103 dan 105 tidak ditulis, artinya galur selain IRH153, HB, IRH330, IRH438, IP13, IG dan MH dari 25 galur produktif. HB: Hawara Bunar, IP13: Inpari 13, IG: Indragiri, MH: Mahsuri. 

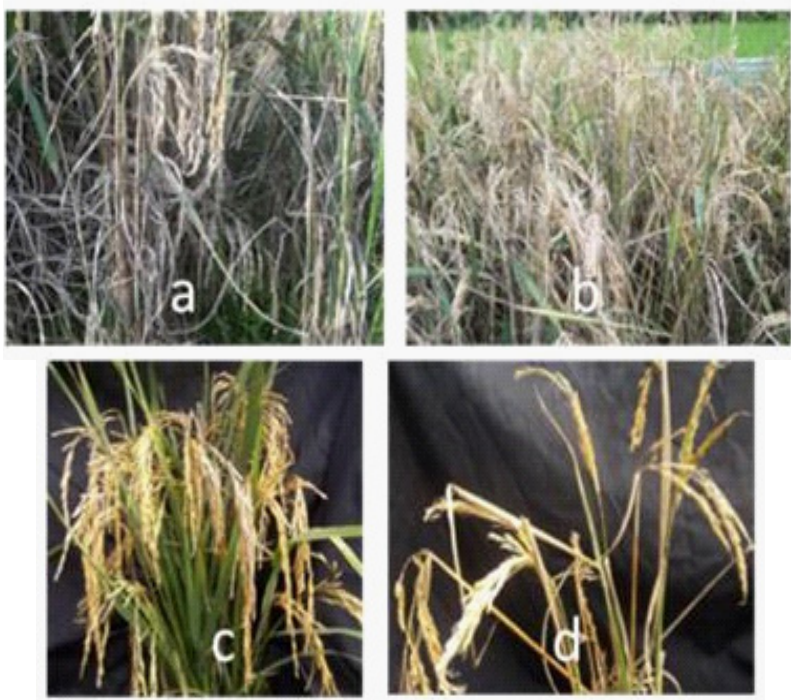

Gambar 1. Contoh-contoh kerusakan akibat serangan penyakit padi pada percobaan lapang. a: IRH94, b: IRH181, c: IR64, d: IRH205.

perlu memperhatikan hasil analisis berbagai peubah yang diteliti mulai dari percobaan pada kultur hara sampai percobaan lapang. Karakteristik penting yang perlu diperhatikan antara lain tingkat bronzing, tinggi tanaman maksimum, jumlah anakan produktif, umur panen, panjang malai, jumlah biji per malai, persen gabah isi, produksi per hektar, bobot 1000 biji, dan ketahanan terhadap penyakit.

Dari 25 galur yang berhasil berproduksi, terdapat 18 galur toleran dan 3 galur kontrol rentan turunan IR64 x Hawara Bunar, dan 4 varietas pembanding. Jika dibandingkan dengan jumlah anakan kedua tetua (var. Hawara Bunar, 5.2 anakan dan var. IR64, 18.7 anakan), maka terdapat 9 galur dengan jumlah anakan produktif mendekati jumlah anakan var. Hawara Bunar, dan 8 galur mendekati jumlah anakan produktif var. IR64. Tinggi tanaman produktif dari 18 galur (selain kontrol dan pembanding) berkisar antara 95.9-174.4 $\mathrm{cm}$ yang berarti ada yang lebih pendek dari padi var. IR64 $(100.9 \mathrm{~cm})$ dan lebih tinggi dari var. Hawara Bunar $(156.7 \mathrm{~cm})$. Dari 18 galur tersebut produksi gabah kering per hektar berkisar antara 1.07-5.05 ton. Jika produksi yang layak diperhitungkan mulai dari 4.50 t/ha, maka hanya ada 6 galur (IRH1, IRH108, IRH195, IRH286, IRH629, IRH715) yang dapat mencapai hasil di atas $4.5 \mathrm{t} / \mathrm{ha}$. Dari 6 galur tersebut karakter panjang malai berkisar antara $22.7-28.7 \mathrm{~cm}$, tetapi masih lebih pendek dari malai var. Hawara Bunar. Jumlah biji dan bobot biji per malai bervariasi berturut-turut dari 78.3-208.5 biji dan 2.0-3.7 gram dengan persen gabah isi dan bobot 1000 biji berturut-turut berkisar antara 70.0$88.5 \%$ dan 23.7-35.5 gram. Dari 6 galur produktif tersebut, hanya IRH1 yang menghasilkan ukuran biji paling kecil. Daya tahan terhadap penyakit dari
6 galur terbaik adalah 3 galur tahan (IRH1, IRH108, IRH195), 1 galur rentan (IRH629), dan 2 galur sangat rentan (IRH286, IRH715).

\section{PEMBAHASAN}

Hasil penapisan 54 galur F8 hasil persilangan var. IR64 $\mathrm{x}$ var. Hawara Bunar sesuai kondisi percobaan diperoleh 25 galur toleran Fe (skor bronzing 3 dan 5). Galur-galur yang rentan Fe mengalami perubahan warna daun dengan cepat (mulai hari ke 4-7) hingga terjadi perubahan warna daun khas bronzing yang bervariasi antara galur yang diuji.

Berdasarkan skor bronzing, dari 54 galur F8 yang ditapis, sebanyak 25 galur tergolong kategori toleran dan moderat toleran (skor $3 \&$ \&), yang berarti galur-galur tersebut berpotensi tahan cekaman Fe di lahan pasang surut dengan $\mathrm{pH}$ sekitar 4.5. Skor bronzing daun menjadi parameter toleransi cekaman Fe pada percobaan kultur hara, karena skor bronzing merupakan respon fenotipe yang mudah teramati langsung, tanpa harus memanen tanaman, sehingga bisa juga digunakan sebagai parameter seleksi di lapang. Gejala keracunan terjadi karena kelebihan penyerapan $\mathrm{Fe}^{2+}$ pada tanaman padi. Dalam jaringan daun tumbuhan, kelebihan $\mathrm{Fe}^{2+}$ teroksidasi menjadi $\mathrm{Fe}^{3+}$ yang menimbulkan radikal bebas, yang selanjutnya bisa merusak jaringan daun, dan akibatnya mengganggu proses fisiologi. Reaksi bisa terjadi antara $\mathrm{O}_{2}+\mathrm{Fe}^{2+}$ à $\mathrm{O}_{2}^{-}+\mathrm{Fe}^{3+}$ atau $\mathrm{H}_{2} \mathrm{O}_{2}$ à $\mathrm{Fe}^{3+}+$ $\mathrm{OH}^{-}+\mathrm{OH}^{\circ}$. Radikal bebas $\mathrm{O}_{2}^{-}, \mathrm{OH}^{-}, \mathrm{OH}^{\circ}$ inilah yang merusak struktur membran sel (fosfolipid, protein), merubah muatan membran, hingga merusak inti sel. Radikal bebas ini juga mengoksidasi klorofil yang mengakibatkan hilangnya warna klorofil, dan dalam kondisi konsentrasi radikal bebas yang tinggi sel daun menjadi mati. Tingkat keracunan berbeda di antara varietas padi, karena proses terjadinya keracunan melibatkan sejumlah faktor dan proses yang kompleks (Becker \& Asch 2005). Gejala bronzing terjadi karena terjadinya peningkatan aktivitas enzin polyphenol oxidase yang menimbulkan teroksidasinya fenol yang mengubah warna daun hijau menjadi coklat kekuningan, warna bronze (Dobermann \& Fairhusrt 2000). Proses kerusakan jaringan daun padi dimulai pada ujung daun karena $\mathrm{Fe}^{2+}$ diangkut dengan cepat lewat xylem yang ujungnya ada pada pinggir daun, kemudian menyebar ke bawah sejalan dengan bertambahnya cekaman Fe (Fageria 2013).

Parameter pertumbuhan fenotipe umur produktif untuk tinggi tanaman dan jumlah anakan semuanya berbeda antar galur yang diuji, karena kedua tetua memiliki tinggi tanaman dan jumlah anakan yang kontras. Varietas IR64 berkarakter pendek (100.9 
cm) dan banyak anakan (18.7 anakan), sedangkan var. Hawara Bunar berkarakter tinggi $(156.7 \mathrm{~cm})$ dan anakan sedikit (5.2 anakan). Galur F8 yang diuji menunjukkan variasi angka sekitar kedua tetua tersebut. Dari semua galur turunan var. IR64 x var. Hawara Bunar tidak ada satupun yang melebihi jumlah anakan tetua IR64, dan hanya ada satu galur, IRH195 (18.5 anakan) yang mendekati jumlah anakan tetua var. IR64. Rerata jumlah anakan produktif galur-galur yang diuji lapang adalah 12.1 anakan. Menurut Abdullah et al (2008) padi tipe baru yang berpotensi hasil tinggi umumnya harus mempunyai sifat-sifat antara lain: jumlah anakan sedang tetapi semua produktif(12-18 batang), jumlah gabah per malai 150-250 butir, persentase gabah isi $85-95 \%$, bobot 1.000 gabah isi 25-26 g, batang kokoh dan pendek (80-90 cm), umur genjah (110-120 hari), tahan terhadap hama dan penyakit utama. Beberapa masyarakat setempat yang menyaksikan karakter var. Hawara Bunar, bermalai panjang, jumlah biji per malai yang banyak, biji gabah yang besar, dan batang tidak mudah rebah, tertarik untuk mencoba mengembangkan pada lahan mereka, meskipun dengan jumlah anakan sedikit. Karakter yang disukai petani sebenarnya jumlah anakan produktif sedang (12-16 batang) dan pendek kokoh yaitu $>$ anakan var. Hawara Bunar (5.2) dan < var. IR64 (18.7). Hal ini didasarkan pada pertimbangan kalau terlalu sedikit anakan bila diserang hama akan mengalami penurunan produksi yang sangat signifikan, seperti pada var. Hawara Bunar. Sebaliknya kalau anakan terlalu banyak rawan terserang penyakit karena kepadatan anakan (Abdullah et al. 2008). Petani menyukai biji gabah 25-26 g per 1000 biji lebih besar dari biji var. IR64 (24 g). Rerata jumlah anakan dari 2 galur toleran terbaik masuk kategori sedang sesuai dengan kriteria yang disampaikan oleh Abdullah et al. (2008). Kedua galur terbaik tersebut juga sudah teruji ketahanannya pada beberapa penyakit yang menyerang.

Karakter reproduktif umur panen menunjukkan waktu yang relatif berdekatan antar galur yang diuji (Tabel 4). Tetua var. Hawara Bunar dapat dipanen pada umur $111 \mathrm{HST}$, dan hampir semua galur yang diuji memiliki umur panen yang lebih cepat dari umur panen tetua tersebut, hanya galur IRH438 yang panen pada umur 112 HST (Tabel 4). Ratarata umur panen dari galur-galur tersebut adalah 104.4 HST, lebih pendek dari harapan karakter padi tipe baru (110-120 hari) seperti yang dinyatakan oleh Abdullah et al. 2008). Berdasarkan tipe luapan lahan (tipe C) tempat percobaan ini, habitus padi yang sesuai dengan kondisi lahan percobaan adalah padi yang memiliki tinggi sama dengan padi sawah konvesional, berbeda dengan habitus tanaman padi yang biasa ditanam pada lahan pasang surut tipe A dan tipe B. Semua parameter generatif yang diamati berbeda nyata antar galur, mengindikasikan bahwa parameter generatif merupakan karakter poligenik. Dari semua galur yang dipelajari, hanya ada satu galur yang melebihi produksi tetua var. Hawara Bunar. Berdasarkan standar minimal produksi (4.5 ton/ha. Tabel 5) yang berpotensi dikembangkan ada 6 galur (IRH1, IRH108, IRH195, IRH286, IRH629, dan IRH715). Produksi galur IRH715 dan IRH286 cukup tinggi (masing-masing 4.84 dan 4.68 ton/ ha) tapi sangat rentan penyakit, sementara IRH629 rentan penyakit dan produksi hanya $4.55 \mathrm{t} / \mathrm{ha}$. Galur IRH715 menghasilkan jumlah anakan lebih banyak (18.5) dengan tanaman lebih pendek (96.1 $\mathrm{cm})$ dibandingkan dengan galur produktif lainnya, sehingga bila dugaan serangan penyakit didukung oleh curah hujan dan kelembaban yang tinggi, maka galur IRH715 bisa ditanam saat curah hujan yang rendah, atau ditanam lebih awal sehingga pada saat curah hujan tinggi sudah bisa panen, atau juga bisa

Tabel 5. Karakter penting galur/varietas produktif yang lebih dari 4.5 ton/ha

\begin{tabular}{|c|c|c|c|c|c|c|c|c|c|c|c|c|}
\hline \multirow{2}{*}{$\begin{array}{c}\text { No } \\
\text { Galur/var }\end{array}$} & \multicolumn{2}{|c|}{ Bronzing } & \multirow{2}{*}{$\begin{array}{l}\text { JAP } \\
\text { (ind) }\end{array}$} & \multirow{2}{*}{$\begin{array}{l}\text { TTP } \\
(\mathrm{cm})\end{array}$} & \multirow{2}{*}{$\begin{array}{c}\text { UP } \\
\text { (HST) }\end{array}$} & \multirow{2}{*}{$\begin{array}{l}\text { PM } \\
(\mathrm{cm})\end{array}$} & \multirow{2}{*}{$\begin{array}{l}\Sigma \mathrm{BM} \\
\text { (biji) }\end{array}$} & \multirow{2}{*}{$\begin{array}{c}\text { BBM } \\
(\mathrm{g})\end{array}$} & \multirow{2}{*}{$\begin{array}{c}\text { GI } \\
(\%)\end{array}$} & \multirow{2}{*}{$\begin{array}{l}\text { Prod } \\
\text { (ton/ha) }\end{array}$} & \multirow{2}{*}{$\begin{array}{l}\text { B1000 } \\
(\mathrm{g})\end{array}$} & \multirow{2}{*}{ DTP } \\
\hline & $\%$ & Skor & & & & & & & & & & \\
\hline IRH1 & 27 & 3 & 8.2 & 127.4 & 103 & 26.0 & 208.5 & 3.7 & 78.6 & 4.60 & 23.7 & $\mathrm{~T}$ \\
\hline IRH108 & 17 & 3 & 13.1 & 148.0 & 103 & 28.7 & 95.3 & 2.5 & 75.8 & 5.05 & 35.5 & $\mathrm{~T}$ \\
\hline IRH195 & 39 & 5 & 12.9 & 141.0 & 103 & 27.0 & 150.9 & 3.2 & 81.5 & 4.75 & 26.6 & $\mathrm{~T}$ \\
\hline IRH286 & 35 & 5 & 13.3 & 100.0 & 105 & 26.7 & 133.3 & 2.7 & 71.1 & 4.68 & 30.9 & SR \\
\hline IRH629 & 15 & 3 & 12.9 & 102.5 & 103 & 22.7 & 89.6 & 2.0 & 70.0 & 4.55 & 32.9 & $\mathrm{R}$ \\
\hline IRH715 & 17 & 3 & 18.5 & 96.1 & 103 & 25.0 & 78.3 & 2.2 & 88.5 & 4.84 & 33.2 & SR \\
\hline HB & 57 & 7 & 5.2 & 156.7 & 111 & 32.3 & 173.1 & 6.2 & 87.6 & 4.83 & 41.6 & $\mathrm{ST}$ \\
\hline IG & & & 16.5 & 120.7 & 119 & 23.7 & 144.7 & 2.5 & 72.7 & 6.13 & 23.8 & $\mathrm{~T}$ \\
\hline MH & 9 & 1 & 12.6 & 135.1 & 132 & 24.3 & 207.1 & 3.2 & 92.3 & 6.51 & 17.3 & ST \\
\hline
\end{tabular}

$\mathrm{HB}=$ Hawara Bunar, IG = Indragiri, MH = Mahsuri, JAP = jumlah anakan produktif (individu), TTP = tinggi tanaman produktif $(\mathrm{cm}), \mathrm{UP}=$ umur panen (HST), $\Sigma \mathrm{BM}=$ jumlah biji per malai (biji), BBM = bobot biji per malai $(\mathrm{g}), \mathrm{GI}=$ persen gabah isi $(\%)$, Prod $=$ produksi per hektar (ton/ha), B1000 = bobot $1000 \mathrm{biji}(\mathrm{g}), \mathrm{DTP}=$ daya tahan terhadap penyakit $(\mathrm{T}=$ tahan, $\mathrm{ST}=$ sangat tahan, $\mathrm{R}$ $=$ rentan, $\mathrm{SR}=$ sangat rentan). 
digunakan untuk persilangan dengan varietas yang tahan penyakit. Tiga galur lain, yaitu IRH1, IRH108, dan IRH195 memiliki potensi untuk dikembangkan sebagai padi pasang surut. Tiga galur tersebut memiliki sifat toleran Fe, tinggi tanaman lebih pendek (127.4-148.0 cm), anakan sedang (12.913.1) kecuali IRH1 hanya 8.2 anakan, umur panen relatif pendek (103-105 HST), dan produksi setara dengan tetua var. Hawara Bunar (4.60-5.05 ton/ha). Hal ini mengindikasikan bahwa tiga galur tersebut telah membawa sifat vegetatif dan reproduktif yang lebih baik dari tetua dengan produktivitas yang sama dengan tetua. Hasil penelitian Suryadi (2012) juga menunjukkan hasil yang sama bahwa galur IRH195 dan IRH715 toleran Fe baik pada percobaan kultur hara maupun lapang.

Dari 3 nomor yang toleran tersebut, galur IRH1 menghasilkan anakan paling sedikit (8.2 anakan), bobot 1000 biji (23.7 g, mirip biji padi var. Indragiri $23.8 \mathrm{~g}$ ), dan produksi paling rendah (4.6 ton/ha). Galur terbaik untuk dikembangkan pada tipe lahan sesuai kondisi penelitian ini adalah galur IRH108 dan IRH195. Kedua galur banyak memiliki kemiripan karakter seperti jumlah anakan, tinggi tanaman, umur panen, panjang malai, persen gabah isi, dan daya tahan terhadap penyakit. Namun demikian produksi kedua galur belum bisa melampaui produksi var. Indragiri (6.13 ton/ha). Produksi galur IRH108 baru bisa mencapai 5.05 ton/ha sedikit di atas produksi tetua Hawara Bunar (4.83 ton/ha). Galur IRH108 dan IRH195 memiliki karakteristik cukup baik untuk dikembangkan pada lahan serupa untuk periode tanam musim hujan dengan karakteristik tanaman agak pendek $(141 \mathrm{~cm}$ dan $148 \mathrm{~cm})$, jumlah anakan sedang (sekitar 13.0 anakan), umur panen lebih pendek (103 HST), dan produksi 4.75 ton/ha (IRH195) dan 5.05 ton/ha (IRH108) gabah kering panen. Disarankan kedua galur potensial ini perlu diuji lapang lagi pada lahan pasang surut dengan kadar Fe lebih tinggi, atau pada masa tanam musim kering (April-Juli).

\section{DAFTAR PUSTAKA}

Abdullah B, Tjokrowidjojo S, Sularso. 2008. Perkembangan dan prospek perakitan padi tipe baru di Indonesia. J Litbang Pertanian, 27(1): 1-9
Agus F, Subiksa IGM. 2008. Lahan gambut: potensi untuk pertanian dan aspek lingkungan. Bogor (ID). Balit Tanah. $36 \mathrm{hlm}$.

Amnal. 2009. Respon fisiologi beberapa varietas padi terhadap cekaman besi [tesis]. Bogor (ID): Institut Pertanian Bogor.

Asch F, Becker M, Kpongor DS. 2005. A quick and efficient screen for resistance to iron toxicity in lowland rice. J Plant Nutr Soil Sci. 168: 764-773

Audebert A- Sahrawat K.L. 2000. Mechanisms for iron toxicity tolerance in lowland rice. J Plant Nutr 23(11 \& 12): 18771885

Audebert A, Narteh LT, Kiepe P, Millar D, Beks B. editor. 2006. Iron toxicity in rice-based systems in West Africa. Accra (Ghana): Print Right. 168 p.

BB Biogen. 2010. Katalog Plasma Nutfah Pangan 2010, Bogor (ID). BB Biogen. 275 hal.

Becker M, Asch F. 2005. Iron toxicity in rice - conditions and management concepts. J Plant Nutr Soil Sci 168: 558-573

Chérif M, Audebert A, Fofana M, Zouzou M. 2009. Evaluation of iron toxicity on lowland irrigated rice in West Africa. Tropicultura 27(2): 88-92.

Daradjat AA, Silitonga S, Nafisah. 2009. Ketersediaan plasma nutfah untuk perbaikan varietas padi. Subang (ID). Publikasi ICRR [BB Padi].

Dobermann A, Fairhurst T. 2000. Rice: Nutrient disorders \& Nutrient Management. Handbook series. $1^{\text {rst }}$ ed. Singapore: Oxford Graphic Printers Pte Ltd. 191 p.

Fageria NK. 2013. Mineral Nutrition of Rice. $1^{\text {rst }}$ ed. Bosa Roca (US): Taylor \& Francis Inc (CRC Press). 586 p.

Humairil R, Khairullah I. 2000. Potensi galur-galur padi rawa pasang surut menunjang ketahanan pangan. Bul Agron 28(3): 73-76.

Kustianto B, Supartopo, Maulana; Harmains A. 2008. Skrining galur-galur padi rawa terhadap keracunan besi di Tamanbogo. Dalam Prosiding Seminar Apresiasi Hasil Penelitian Padi 2007. Sukamandi (ID): BB Penelitian Tanaman Padi: 697703 .

Moeljopawiro S, Suprihatno B, Orbani IN. 2003. Panduan karakterisasi dan evaluasi tanaman padi. Bogor (ID): Balitbang Pertanian. $58 \mathrm{hlm}$.

Satoto- Suprihatno B. 2008. Pengembangan padi hibrida di Indonesia. Iptek Tanaman Pangan 3(1): 27-40.

Silitonga TS. 2004. Pengelolaan dan pemanfaatan plasma nutfah padi di Indonesia. Bul Plasma Nutfah 10 (2):56-71

Suryadi D. 2012. Penapisan galur-galur padi (Oryza sativa L.) populasi RIL F7 hasil persilangan antara varietas IR64 dan Hawara Bunar terhadap cekaman besi [tesis]. Bogor (ID): Institut Pertanian Bogor.

Sutami, Azzahra F, Imberan M. 2003. Penampilan dua belas galur padi terpilih hasil persilangan dan introdulksi di lahan pasang surut bergambut. Bul. Agron. (31): 89 - 93.

Sutami. 2004. Potensi hasil galur-galur padi pasang surut terpilih pada kondisi lahan pasang surut sulfat masam. Agrosains 